\begin{tabular}{|cl}
\hline Jurnal Teknologi Kimia Unimal & $\begin{array}{l}\text { Jurnal } \\
\text { Teknologi } \\
\text { Kimia } \\
\text { Unimal } \\
\text { http://ojs.unimal.ac.id/index.php/jtk }\end{array}$ \\
\hline
\end{tabular}

\title{
Pengaruh Waktu Fermentasi dan Volume Bio Aktivator EM 4 (Effective Microorganisme) pada Pembuatan Pupuk Organik Cair (POC) dari Limbah Buah-Buahan
}

\author{
Meriatna, Suryati, Aulia Fahri*) \\ Program Studi Teknik Kimia, Fakultas Teknik, Universitas Malikussaleh \\ *E-mail: auliafahri52@gmail.com
}

\begin{abstract}
Abstrak
Pembuatan pupuk organik cair khususnya dari limbah buah-buahan dengan penambahan bio aktivator EM4 (Effective Microorganisme) bertujuan untuk menentukan pengaruh waktu pembuatan terhadap kandungan Nitrogen $(N)$, Phosfor $\left(\mathrm{P}_{2} \mathrm{O}_{5}\right)$, dan Kalium $\left(\mathrm{K}_{2} \mathrm{O}\right)$ dalam pupuk organik cair, serta menentukan pengaruh bio aktivator $E_{4}$ terhadap kandungan $N, P, K$. Metode pembuatan pupuk organik cair ini yaitu limbah buah-buahan seperti buah semangka, jeruk, dan buah pepaya yang banyak mengandung air dihancurkan sebelum di fermentasikan. Kemudian bio aktivator EM 4 disiapkan untuk penambahan dalam limbah buah-buahan yang sudah dikecilkan ukurannya. Limbah buah-buahan dimasukkan ke dalam galon air 5 liter, larutan bio aktivator EM 4 kemudian dimasukkan ke dalam galon secara merata. Pengambilan sampel dilakukan berdasarkan variasi waktu 10 hari, 13 hari dan 16 hari serta variasi penambahan jumlah bio aktivator EM4 sebanyak $40 \mathrm{ml}, 50 \mathrm{ml}$, dan $60 \mathrm{ml}$. Hasil penelitian menunjukkan bahwa kadar N, P, K terbaik didapat pada hari ke 13 dengan volume bio aktivator $\mathrm{EM}_{4} 60 \mathrm{ml}$, untuk kandungan nitrogen yaitu 13,4\%, untuk kandungan phosfor 10,92 \%, dan untuk kandungan kalium yaitu 6,39\%. Volume bio aktivator EM4 sangat berpengaruh terhadap kandungan $N, P$, dan $K$, dikarenakan semakin banyak volume bio aktivator EM4 maka kadar $N$, $P$, dan $K$ juga akan semakin tinggi.
\end{abstract}

Kata kunci: effective microorganisme, nitrogen, phosfor, kalium, pupuk organik cair

\section{Pendahuluan}

Sampah adalah sisa-sisa bahan yang telah mengalami perlakuan, telah diambil bagian utamanya, telah mengalami pengolahan, dan sudah tidak bermanfaat, dari segi ekonomi sudah tidak ada harganya lagi dan dari segi lingkungan dan menyebabkan pencemaran atau gangguan kelestarian alam (Amurwaraharja, 2006). 


\section{Jenis-jenis Sampah:}

a. Sampah organik

Sampah organik berasal dari makhluk hidup, baik manusia, hewan, maupun tumbuhan. Sampah organik sendiri dibagi menjadi sampah organik basah dan sampah organik kering. Istilah sampah organik basah dimaksudkan sampah yang mempunyai kandungan air yang cukup tinggi. Contohnya kulit buah dan sisa sayuran. Sedangkan bahan yang termasuk sampah organik kering adalah sampah yang mempunyai kandungan air yang rendah. Contoh sampah organik kering adalah kayu dan ranting kering, dan dedaunan kering.

Jenis sampah organik yang bisa diolah menjadi pupuk organik adalah :

1. Sampah sayur baru

2. Sisa sayur basi, tetapi ini harus dicuci dulu, peras, lalu buang airnya.

3. Sisa nasi

4. Sisa ikan, ayam, kulit telur.

5. Sampah buah (semangka, kulit jeruk, pepaya dan lain-lain). Tapi tidak termasuk kulit buah keras seperti kulit salak.

Jenis sampah organik yang tidak bisa diolah :

1. Protein seperti daging, ikan, udang, juga lemak, santan, susu karena mengandung lalat sehingga tumbuh belatung.

2. Biji-bijian yan utuh atau keras seperti biji salak, asam, lengkeng, alpukat dan sejenisnya.

3. Sisa sayur yang berkuah harus dibuang airnya, kalau bersantan harus dibilas dengan air dan tiriskan (Litauditomo, 2007).

b. Sampah anorganik

Sampah anorganik bukan berasal dari makhluk hidup. Sampah berasal dari bahan yang bisa diperbaharui (recycle) dan sampah ini sangat sulit terurai oleh jasad renik. Jenis sampah ini misalnya bahan yang terbuat dari plastik dan logam.

c. Sampah B3 (bahan berbahaya dan beracun) 
Sampah B3 merupakan jenis sampah yang dikategorikan beracun dan berbahaya bagi manusia. Umumnya, sampah ini mengandung merkuri seperti kaleng bekas, cat semprot, atau minyak wangi (Purwendro, 2007).

\section{Pupuk Organik}

Pupuk organik merupakan bahan yang berasal dari sisa-sisa tanaman, hewan, seperti pupuk kandang, kompos, pupuk hijau, jerami, dan bahan lain yang dapat berperan memperbaiki sifat fisik, kimia dan biologi tanah. Bahan organik tidak dapat menggantikan peran dari pupuk anorganik sebagai pemasok hara, karena kandungan unsur hara dalam bahan organik relatif rendah, namun demikian bahan organik dapat meningkatkan efisiensi penggunaan pupuk anorganik (Soedardjo dan Mashuri, 2000).

Pupuk organik mengandung unsur karbon dan nitrogen dalam jumlah yang sangat bervariasi, dan imbangan unsur tersebut sangat penting dalam mempertahankan atau memperbaiki kesuburan tanah. Nisbah karbon nitrogen tanah harus selalu dipertahankan setiap waktu karena nisbah kedua unsur tersebut merupakan salah satu kunci penilaian kesuburan tanah. Nisbah $\mathrm{C} / \mathrm{N}$ kebanyakan tanah subur berkisar 1 sampai 2. Penambahan bahan organik dengan nisbah $\mathrm{C} / \mathrm{N}$ tinggi mengakibatkan tanah mengalami perubahan imbangan $\mathrm{C}$ dan $\mathrm{N}$ dengan cepat, karena mikroorganisme tanah menyerang sisa pertanaman dan terjadi perkembangbiakan secara cepat (Sutanto, 2002).

Pupuk organik merupakan bahan pembenah tanah yang paling baik dan alami dari pada bahan pembenah buatan/sintesis. Pada umumnya pupuk organik mengandung hara makro $\mathrm{N}, \mathrm{P}, \mathrm{K}$ rendah tetapi mengandung hara mikro dalam jumlah cukup yang sangat diperlukan pertumbuhan tanaman. Sebagai bahan pembenah tanah, pupuk organik mencegah terjadinya erosi, pergerakan permukaan tanah (Crusting) dan retakan tanah, mempertahankan kelengasan tanah serta memperbaiki pengatusan dakhil (internal drainase). Penempatan pupuk organik kedalam tanah dapat dilakukan seperti pupuk kimia (Sutanto, 2002). 
Pupuk organik bukanlah untuk menggantikan peran pupuk kimia melainkan sebagai pelengkap fungsi pupuk kimia. pupuk organik dan pupuk kimia akan lebih optimal dan lebih efisien penggunaannya bila dimanfaatkan secara bersama-sama. Penambahan pupuk organik dapat mengurangi dampak negatif pupuk kimia serta memperbaiki sifat fisik, biologi dan kimia tanah secara bersamaan (Wahyono, 2011). Adapun karakteristik umum yang dimilki oleh pupuk organik adalah sebagai berikut:

1. Kandungan hara rendah, kandungan hara pupuk organik pada umumnya rendah tetapi bervariasi tergantung pada jenis bahan dasarnya.

2. Ketersediaan unsur hara lambat, hara yang berasal dari bahan organik diperlukan untuk kegiatan mikrobia tanah untuk diubah dari bentuk ikatan kompleks organik yang tidak dapat dimanfatkan oleh tanaman menjadi bentuk senyawa organik dan anorganik sederhana yang dapat diserap oleh tanaman.

Menyediakan hara dalam jumlah terbatas, penyediaan hara dari pupuk organik biasanya terbatas dan tidak cukup dalam menyediakan hara yang diperlukan tanaman (Sutanto, 2002).

\section{Pupuk Organik Cair}

Menurut Simamora, dkk (2005) pupuk cair organik adalah pupuk yang bahan dasarnya berasal dari hewan atau tumbuhan yang sudah mengalami fermentasi dan bentuk produknya berupa cairan. Kandungan bahan kimia di dalamnya maksimal 5\%. Penggunaan pupuk cair memiliki beberapa keuntungan sebagai berikut:

1. Pengaplikasiannya lebih mudah jika dibandingkan dengan pengaplikasian pupuk organik padat.

2. Unsur hara yang terdapat dalam pupuk cair mudah diserap tanaman.

3. Mengandung mikroorganisme yang jarang terdapat dalam pupuk organik padat. 
4. Pencampuran pupuk cair organik dengan pupuk organik padat mengaktifkan unsur hara yang ada dalam pupuk organik padat tersebut (Simamora dkk, 2005).

Sedangkan menurut Hadisuwito (2007), pupuk organik cair adalah larutan dari hasil pembusukan bahan-bahan organik yang berasal dari sisa tanaman, kotoran hewan, dan manusia yang kandungan unsur haranya lebih dari satu unsur. Kelebihan dari pupuk organik ini dapat secara cepat mengatasi defisiensi hara, tidak bermasalah dalam hal pencucian hara, dan mampu menyediakan hara secara cepat. Dibandingkan dengan pupuk cair anorganik, pupuk organik cair secara umumnya tidak merusak tanah dan tanaman walaupun digunakan sesering mungkin. Selain itu, pupuk ini juga memiliki bahan pengikat, sehingga larutan pupuk yang diberikan kepermukaan tanah bisa langsung digunakan oleh tanaman (Hadisuwito, 2007).

\section{Klasifikasi Pupuk Organik Cair}

\section{a. Pupuk Kandang Cair}

Pupuk kandang dapat pula digunakan dalam bentuk cair. Pupuk kandang cair dapat dibuat dengan mencampurkan kotoran hewan dengan air lalu diaduk. Setelah larutan tercampur rata simpanlah di tempat yang teduh dan tidak terkena sinar matahari langsung dengan memberi penutup atau pelindung. Penyimpanan pupuk kandang cair dilakukan dengan kondisi tertutup agar udara tidak dapat masuk. Hal ini dilakukan untuk menekan kehilangan nitrogen dalam bentuk gas amoniak yang menguap. Dengan menyimpannya terlebih dahulu sebelum digunakan akan meningkatkan kandungan fosfat dan membuat kandungan hara menjadi seimbang. Penggunaan pupuk kandang cair juga akan meningkatkan efisien penggunaan phosfat oleh tanaman.

Seperti halnya pupuk organik padat, pupuk kandang cair juga berasal dari kotoran hewan. Namun pupuk kandang cair berasal dari urin ternak. Adapun tabel 2.1 ini adalah tabel kandungan hara makro dengan beberapa jenis kotoran padat dan cair. 
Tabel 2.1 Kandungan Hara Makro Beberapa Jenis Kotoran Padat dan Cair

\begin{tabular}{|c|c|c|c|c|c|}
\hline \multirow{2}{*}{ Jenis } & \multirow{2}{*}{ Jenis } & \multicolumn{4}{|c|}{ Kandungan Hara Makro (\%) } \\
\cline { 3 - 6 } & kotoran & Nitrogen & Fosfor & Kalium & Kalsium \\
\hline Kuda & Padat & 0,56 & 0,13 & 0,23 & 0,12 \\
& Cair & 1,24 & 0,001 & 1,26 & 0,32 \\
\hline Kerbau & Padat & 0,26 & 0,08 & 0,14 & 0,33 \\
& Cair & 1,62 & - & 1,34 & - \\
\hline Domba & Padat & 0,65 & 0,22 & 0,14 & 0,33 \\
& Cair & 1,43 & 0,01 & 0,55 & 0,11 \\
\hline Sapi & Padat & 0,33 & 0,11 & 0,13 & 0,26 \\
& & 1,52 & 0,01 & 0,56 & 0,007 \\
\hline Babi & Padat & 1,57 & 0,17 & 0,38 & 0,06 \\
& Cair & 0,31 & 1,05 & 0,81 & - \\
\hline
\end{tabular}

SNI : 19-7030-2004 (Badan Standarisasi Nasional, 2011).

Dalam penggunaan pupuk kandang perlu diwaspadai dalam penggunaan langsung dalam tanaman adalah kemungkinan adanya kandungan gulma, organisme penyebab penyakit yang terkandung dalam pupuk kandang atau kotoran hewan. Penggunaan secara langsung kemungkinan besar akan terjadi panas karena proses penguraian.

Pupuk kandang merupakan pupuk organik dapat berperan sebagai bahan pembenah tanah. Pupuk kandang dapat mencegah erosi, pergerakan tanah dan retakan tanah. Pupuk kandang dan pupuk organik lainnya meningkatkan kemampuan tanah mengikatkan kelembaban, memperbaiki struktur tanah dan pengerasan tanah. Pupuk kandang memicu pertumbuhan dan perkembang bakteri dan mahkluk tanah lainnya. Pupuk kandang mempunyai kandungan unsur $\mathrm{N}, \mathrm{P}, \mathrm{K}$ rendah, tetapi banyak mengandung unsur mikro. Kandungan unsur nitrogen dalam pupuk kandang akan dilepaskan secara perlahan-lahan, dengan demikian pemberian pupuk kandang yang berkelanjutan akan membantu dalam membangun kesuburan tanah dalam jangka panjang. 
Nilai dari pupuk kandang tidak hanya didasarkan pada pasokan jumlahnya tetapi jumlah nitrogen dan zat yang terkandung. Nitrogen yang dilepaskan dengan adanya aktivitas mikroorgnisme kemudian dimanfaatkan oleh tanaman. Berbagai contoh di atas memperlihatkan bahwa banyak sekali bahan yang dapat digunakan sebagai pupuk. Memang dalam penggunaannya pupuk organik ini memiliki kelemahan dibandingkan dengan pupuk kimia. Meskipun begitu pupuk organik memiliki banyak kelebihan yang tidak dapat digantikan dengan pupuk kimia. Selain itu penggunaan pupuk organik dapat melepaskan ketergantungan petani dari dunia luar dalam hal ini pabrik pupuk, dengan membiasakan kembali penggunaan pupuk organik akan menjadikan petani tidak menjadi tidak terombang ambingkan oleh perusahaan-perusahaan pupuk baik kimia maupun pabrik pupuk organik (Hadisuwito, 2012).

\section{b. Pupuk Cair Limbah Organik}

Pada dasarnya, limbah cair dari bahan organik bisa dimanfaatkan sebagai pupuk. Sama seperti limbah padat organik, limbah cair banyak mengandung unsur hara, khususnya N, P, K dan bahan organik lainnya. Penggunaan pupuk dari limbah ini dapat membantu memperbaiki struktur dan kualitas tanah. Dari sebuah penelitian di China menunjukan penggunaan limbah cair organik mampu meningkatkan produksi pertanian $11 \%$ lebih tinggi dibandingkan dengan menggunakan bahan organik lain. Bahkan di China penggunaan pupuk kimia sintetik untuk pupuk dasar mulai tergeser dengan keunggulan pupuk cair organik.

\section{c. Pupuk Cair Limbah Manusia}

Pupuk cair dari kotoran manusia sebenarnya merupakan campuran antara kotoran manusia dan cairan yang keluar bersamaan dengan kotoran manusia. Kotoran manusia merupakan komponen utama dari limbah cair organik rumah tangga. Kandungan haranya berbeda-beda tergantung makanannya yang dikonsumsinya. Di negara-negara seperti China, Taiwan, Korea, dan Jepang, pemanfaatan kotoran manusia sebagai pupuk organik telah lama dikembangkan secara tradisional. Bahkan di China telah ada cara khusus untuk mengumpulkan 
kotoran manusia. Untuk memanfaatkan kotoran manusia menjadi pupuk, cukup dilakukan dengan teknik pengolahan yang sederhana tanpa melalui biogas (Hadisuwito, 2007).

\section{Effective Microorganisme 4 (EM4)}

Effective Microorganisme $4 \quad\left(\mathrm{EM}_{4}\right)$ merupakan campuran dari mikroorganisme yang menguntungkan. Jumlah mikroorganisme fermentasi di dalam $\mathrm{EM}_{4}$ sangat banyak, sekitar 80 jenis. Mikroorganisme tersebut dipilih yang dapat bekerja secara efektif dalam menfermentasikan bahan organik. Dari sekian banyak mikroorganisme, ada lima golongan yang pokok yaitu bakteri fotosintetik, lactobacillus sp, streptomices sp, ragi (yeast), dan actinomicetes.

Efective Microorganisme $4\left(\mathrm{EM}_{4}\right)$ bagi tanaman tidak terjadi secara langsung. Penggunaan $\mathrm{EM}_{4}$ akan lebih efisien bila terlebih dahulu ditambahkan bahan organik yang berupa pupuk organik ke dalam tanah. $\mathrm{EM}_{4}$ akan mempercepat fermentasi bahan organik sehingga unsur hara yang terkandung akan terserap dan tersedia bagi tanaman, $\mathrm{EM}_{4}$ juga sangat efektif digunakan sebagai pestisida hayati yang bermanfaat untuk meningkatkan kesehatan tanaman $\mathrm{EM}_{4}$ juga bermanfaat untuk sektor perikanan dan peternakan.

Kelebihan dari $\mathrm{EM}_{4}$ ini adalah bahan yang mampu mempercepat proses pembentukan pupuk organik dan meningkatkan kualitasnya. Selain itu, $\mathrm{EM}_{4}$ mampu memperbaiki struktur tanah menjadi lebih baik serta menyuplai unsur hara yang dibutuhkan tanaman. Kegiatan atau manfaat masing-masing mikroorganisme yang terkandung di dalam $\mathrm{EM}_{4}$ di dalam tanah adalah sebagai berikut :
a. Bakteri fotosintetik (Rhodopseudomonas sp)
b. Bakteri asam laktat (lactobacillus)
c. Streptomycetes s.p
d. Actinomicetes
e. Ragi/yeast 


\section{Bahan dan Metode}

\section{Alat}

Alat-alat yang digunakan adalah galon air, timbangan, $\mathrm{pH}$ meter, pipet ukur, gelas ukur, sarung tangan, blender, hot plate, sepasang alat titrasi, Erlenmeyer, labu ukur $500 \mathrm{ml}$, pipet tetes, labu ukur $50 \mathrm{ml}$.

\section{Bahan}

Bahan-bahan yang digunkana dalam penelitian ini adalah limbah buahbuahan, EM4 (Effective Microorganisme), gula merah, air, $\mathrm{H}_{2} \mathrm{SO}_{4}$ pekat, indikator $\mathrm{PP}, \mathrm{NaOH} 50 \%$, Ammonium molybadate vanadate.

\section{Variabel Penelitian}

\section{Variabel Bebas}

1. Waktu fermentasi (hari) : 10 hari, 13 hari, 16 hari

2. Volume $\mathrm{EM}_{4}(\mathrm{ml})$ : $40 \mathrm{ml}, 50 \mathrm{ml}, 60 \mathrm{ml}$

\section{Variabel Tetap}

1. Limbah buah-buahan : 2000 gr

2. Air gula merah : $600 \mathrm{ml}$

\section{Variabel Terikat}

1. Uji kandungan Nitrogen

3. Uji kandungan Phosfor

4. Uji kandungan Kalium

5. Uji pH (derajat keasaman)

\section{Prosedur Penelitian}

Proses persiapan sampel pupuk organik cair berlangsung secara anaerob persiapannya yang pertama yaitu menyiapkan limbah buah-buahan ditimbang 6000 gr, kemudian dipotong-potong untuk memperkecil ukuran agar mempermudah saat diblender. Setelah halus kemudian dimasukkan masing- 
masing 2000 gr ke dalam 3 buah gallon air yang berukursan 5 liter. Galon pertama ditambahkan $\mathrm{EM}_{4} 40 \mathrm{ml}$ dan air gula merah $600 \mathrm{ml}$, untuk galon ke dua ditambahkan $\mathrm{EM}_{4} 50 \mathrm{ml}$ dan air gula merah $600 \mathrm{ml}$, dan untuk ke tiga ditambahkan $\mathrm{EM}_{4} 60 \mathrm{ml}$ dan air gula merah $600 \mathrm{ml}$. Kemudian larutan diaduk sampai campuran di dalam gallon homogeny, lalu ditutup masing-masing dengan tutup plastik. Selanjutnya fermentasi dan lakukan pengamatan 10, 13, 16 hari hingga diperoleh cairan kental atau pupuk organik cair, kemudian pupuk organik cair disaring agar terpisah dari ampas buahnya. Sampel yang diperoleh, kandungan $\mathrm{N}, \mathrm{P}, \mathrm{K}$ dan $\mathrm{pH}$ dianalisa, masing-masing menggunakan metode mikro kjehdal (untuk N), spektrofotometer (untuk P), flamephotometer (untuk K). pH meter (untuk $\mathrm{pH}$ ).

\section{Hasil dan Diskusi}

Penelitian ini bertujuan untuk membuat sekaligus mengetahui proses yang efektif dalam pembuatan pupuk organik cair dengan memanfaatkan sampah organik dari pasar sebagai bahan bakunya dan dengan penambahan EM4. Adapun untuk mengetahui efektif atau tidaknya proses tersebut adalah dengan membandingkan kandungan $\mathrm{N}, \mathrm{P}, \mathrm{K}$ dan $\mathrm{pH}$ dari masing-masing sampel yang dihasilkan pada variasi lamanya proses pengomposan yaitu 10, 13, dan 16 hari dengan memvariasikan penambahan volume bio aktivator $\mathrm{EM}_{4}$ sebanyak 40, 50, dan $60 \mathrm{ml}$, kemudian membandingkanya dengan standar baku dari pemerintah berdasarkan peraturan menteri pertanian No. 2/pert/HK. 060/2/2006. N, P, K merupakan beberapa unsur hara makro yang sangat dibutuhkan oleh tanaman.

Adapun hasil penelitian kandungan N, P, K dalam sampel yang dihasilkan pada peelitan kali ini adalah sebagai berikut:

Gambar 1 menunjukkan bahwa pengaruh waktu fermentasi terhadap kandungan nitrogen, yang divariasikan dengan menggunakan effective microorganisme $\mathrm{EM}_{4}$, yaitu dapat dilihat digambar pada waktu 10 hari dengan menggunakan volume $\mathrm{EM}_{4} 40 \mathrm{ml}, 50 \mathrm{ml}$, dan $60 \mathrm{ml}$, kandungan nitrogen yang diperoleh adalah 7,3\%, 10,3\% dan 11,6\%. Kadar nitrogen yang terendah yang 
terdapat pada waktu fermentasi 10 hari yaitu 7,3 \%, pada volume $\mathrm{EM}_{4} 40 \mathrm{ml}$, hal ini disebabkan karena dalam waktu fermentasi 10 hari terjadi pertumbuhan mikroorganisme pada fase awal merupakan periode adaptasi yakni sejak inokulasi pada medium dilakukan, selama fase awal ini massa sel dapat berubah tanpa adanya perubahan jumlah sel (Tejasarwana, 1995).

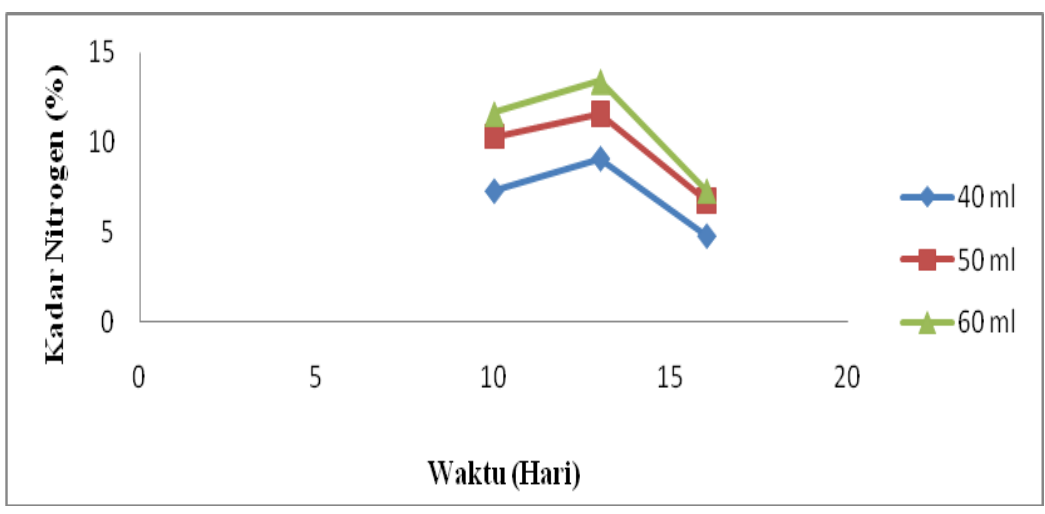

Gambar 1. Grafik pengaruh waktu fermentasi terhadap kandungan nitrogen

Waktu fermentasi 13 hari dengan kadar nitrogen yang didapat 9,1\% pada volume $\mathrm{EM}_{4} 40 \mathrm{ml}, 11,6 \%$ pada volume $\mathrm{EM}_{4} 50 \mathrm{ml}$, dan $13,4 \%$ pada volume $\mathrm{EM}_{4} 60 \mathrm{ml}$, menunjukkan bahwa kandungan nitrogen yang didapatkan semakin tinggi, hal tersebut disebabkan karena pertumbuhan mikroorganisme mengalami fase eksponensial yaitu terjadi pembelahan sel yang sangat cepat. Kadar nitrogen yang mendekati standar kandungan hara pupuk organik cair (SNI : 19-7030-2011) didapatkan pada volume $\mathrm{EM}_{4} 60 \mathrm{ml}$ dan waktu fermentasi 13 hari adalah 13,4\%, menunjukkan bahwa terjadinya pembelahan sel dari mikroorganisme yang sempurna (Tejasarwana, 1995).

Waktu 16 hari, kadar nitrogen yang diperoleh sudah mulai menurun, yaitu 4,8 \% pada volume $\mathrm{EM}_{4} 40 \mathrm{ml}, 6,7 \%$ untuk volume $\mathrm{EM}_{4} 50 \mathrm{ml}$, dan 7,3 \% pada volume $\mathrm{EM}_{4} 60 \mathrm{ml}$, hal ini dipengaruhi oleh pertumbuhan mikroorganisme dan nutrisi yang tersedia sudah mulai berkurang dan sel mulai berhenti membelah diri atau sel hidup dan sel mati mulai mencapai kesetimbangan (Tejasarwana, 1995). 


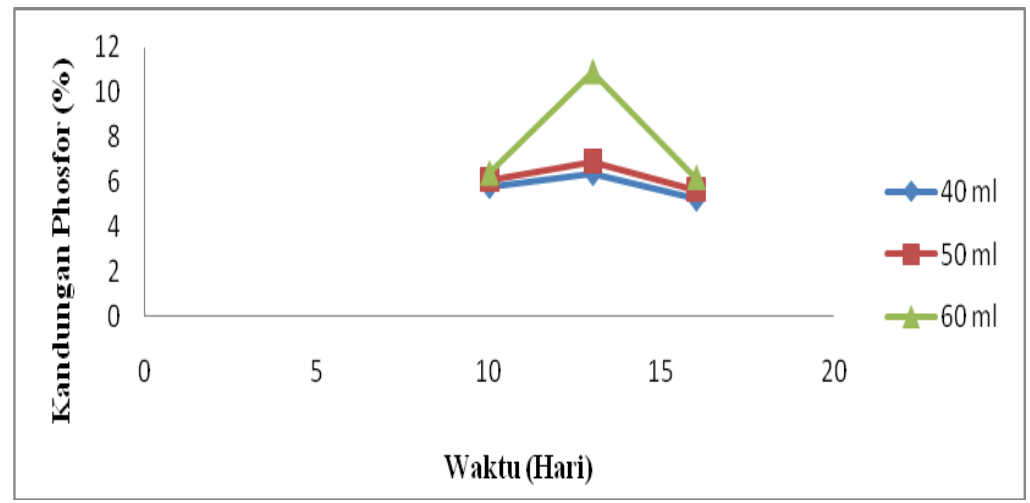

Gambar 2. Grafik pengaruh waktu fermentasi terhadap kandungan phosfor

Gambar 2 menunjukkan bahwa kandungan phosfor sangat dipengaruhi oleh lamanya waktu fermentasi dan jumlah volume $\mathrm{EM}_{4}$ yang divariasikan. Semakin banyak volume $\mathrm{EM}_{4}$ yang divariasikan, semakin tinggi kandungan phosfor yang didapatkan dalam pupuk organik cair. Dapat dilihat digambar bahwa pada waktu 10 hari dengan di variasikan volume effective mikroorganisme $\mathrm{EM}_{4}$ pada $40 \mathrm{ml}$, kadar phosfor yang diperoleh 5,78 \%, pada volume $\mathrm{EM}_{4} 50 \mathrm{ml}$, kadar phosfor yang diperoleh 6,08 \%, dan pada volume $\mathrm{EM}_{4} 60 \mathrm{ml}$, kadar phosfor yang diperoleh $6,36 \%$. Kandungan phosfor yang terendah pada waktu fermentasi 10 hari yaitu pada volume $\mathrm{EM}_{4} 40 \mathrm{ml}$ yaitu $5,78 \%$, hal ini disebabkan karena dalam fermentasi terjadi pertumbuhan mikroorganisme pada fase awal merupakan periode adaptasi yakni sejak inokulasi pada medium dilakukan selama fase awal ini massa sel dapat berubah tanpa adanya perubahan jumlah sel (Tejasarwana, 1995).

Setelah perubahan, massa selanjutnya pertumbuhan mikroorganisme bergerak kearah fase eksponensial, yaitu pada ke 13 hari, dimana terjadi perubahan sangat cepat terhadap jumlah sel. Pada waktu fermentasi 13 hari, dengan memvariasikan volume $\mathrm{EM}_{4} 40 \mathrm{ml}$, kadar phosfor yang diperoleh adalah 6,37 \%, pada volume $\mathrm{EM}_{4} 50 \mathrm{ml}$, kadar phosfor yang diperoleh adalah 6,91\%, dan pada volume $\mathrm{EM}_{4} 60 \mathrm{ml}$, kadar phosfor yang diperoleh adalah 10,92 \%, hal ini menunjukkan bahwa kadar phosfor yang didapatkan sudah mendekati standar kandungan hara pupuk organik cair (SNI : 19-7030-2011), yaitu pada volume $\mathrm{EM}_{4} 60 \mathrm{ml}$, persen phosfor diperoleh 10,92\%, pada waktu 13 hari, dengan 
menggunakan effective microorganisme $\mathrm{EM}_{4}$ itu sangat bagus dalam pembuatan pupuk organik cair, dikarenakan $\mathrm{EM}_{4}$ itu dapat mempercepat reaksi dalam proses fermentasi, kemudian $\mathrm{EM}_{4}$ juga dapat memperbanyak kandungan hara dari pupuk itu sendiri (Tejasarwana, 1995).

Waktu 16 hari, persen phosfor yang diperoleh pada volume bio aktivator $\mathrm{EM}_{4} 40 \mathrm{ml}$ adalah 5,22 \%, pada volume $\mathrm{EM}_{4} 50 \mathrm{ml}$ kadar phosfor yang diperoleh adalah 5,64 \%, dan pada volume bio aktivator $\mathrm{EM}_{4} 60 \mathrm{ml}$ kadar phosfor yang diperoleh adalah $6,16 \%$, hal tersebut disebabkan karena terjadinya pembelahan sel yang sangat tinggi (fase eksponensial), dimana kondisi ini tergantung pada konsentrasi nutrient yang ada. Ketika konsentrasi nutrient mulai berkurang maka pertumbuhan mikroba mulai menurun sampai pertumbuhan mikroorganisme nol, fase ini disebut juga fase stasioner (Said, 1987).

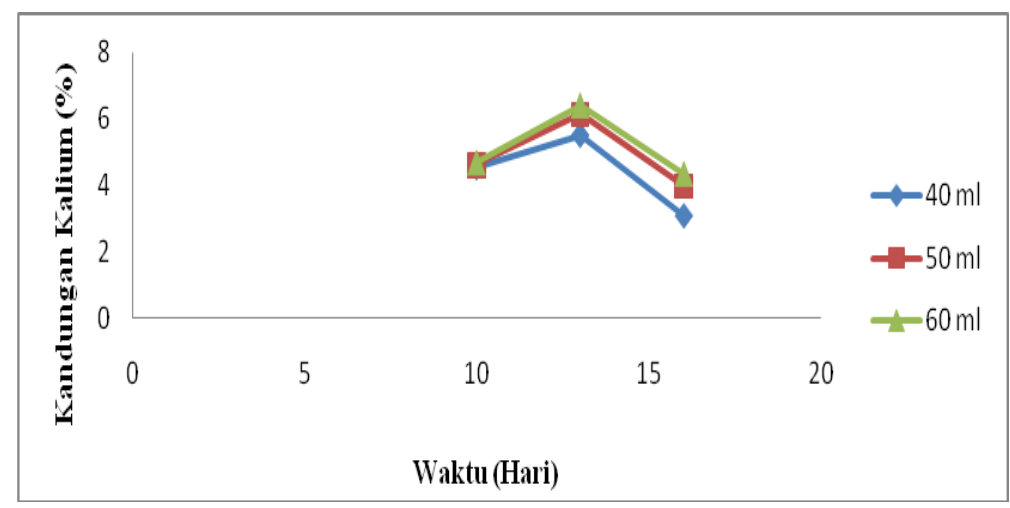

Gambar 3. Grafik pengaruh waktu fermentasi terhadap kandungan kalium

Gambar 3 menunjukkan bahwa pengaruh waktu fermentasi terhadap persen kalium, yang divariasikan dengan effective microorganisme $\mathrm{EM}_{4}$, seperti yang terlihat pada gambar hasil yang terbaik yaitu diperoleh pada waktu fermentasi 13 hari, dengan kadar kalium diperoleh 6,39 \%, dengan menggunakan volume $\mathrm{EM}_{4} 60 \mathrm{ml}$, hal ini menunjukkan bahwa persen kalium yang didapakan ternyata paling tinggi pada waktu 13 hari, dengan divariasikan volume $\mathrm{EM}_{4} 60 \mathrm{ml}$ dibandingkan dengan waktu fermentasi yang lainnya, hal tersebut disebabkan karena pada waktu 13 hari terjadi pembelahan sel yang sempurna yaitu terjadi pada fase eksponensial. Dengan menggunakan effective microorganisme $\mathrm{EM}_{4}$ itu 
sangat bagus dalam pembuatan pupuk organik cair, dikarenakan $\mathrm{EM}_{4}$ itu dapat mempercepat reaksi dalam proses fermentasi, kemudian $\mathrm{EM}_{4}$ juga dapat memperbanyak kandungan hara dari pupuk itu sendiri. Dengan persen kalium yang didapatkan dalam pupuk cair sebanyak 6,39 \%, ini sudah mendekati dengan standar kandungan hara pupuk organik cair (SNI : 19-7030-2011). Namun belum mencapai presentase yang diharapkan karena dipengaruhi oleh masuknya udara luar kedalam reaktor fermentasi sehingga memungkinkan bercampurnya bakteri yang tidak diinginkan diantara keduanya.

Waktu fermentasi 16 hari, dengan divariasikan volume $\mathrm{EM}_{4} 40 \mathrm{ml}, 50 \mathrm{ml}$, dan $60 \mathrm{ml}$ persen kalium yang diperoleh adalah 3,09\%, 3,97 \%, dan 4,35\%. Pada grafik dapat dilihat kandungan kalium yang dihasilkan sudah mulai menurun, hal ini disebabkan karena nutrisi yang tersedia mulai berkurang dan sel mulai berhenti membelah diri, atau sel hidup dan sel mati mulai mencapai kesetimbangan.

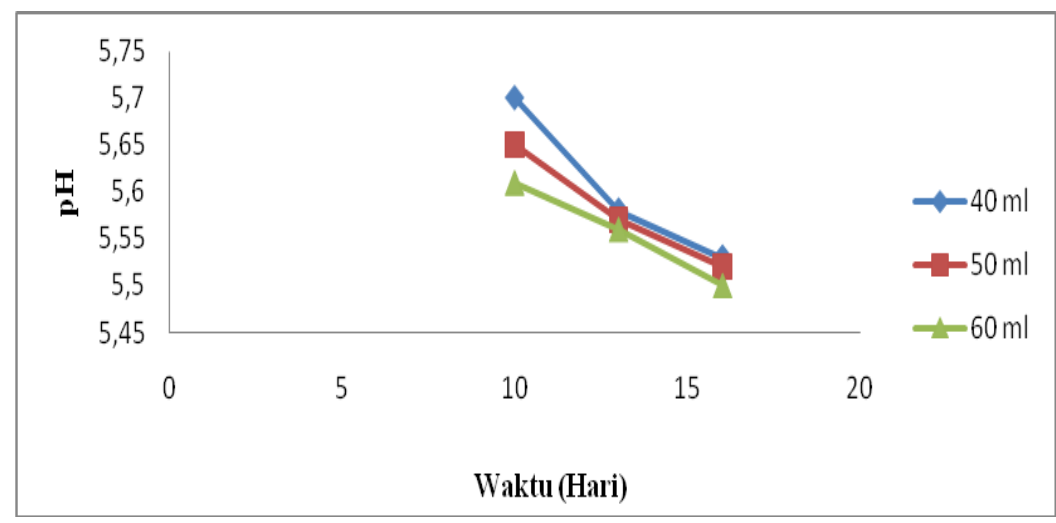

Gambar 4. Grafik pengaruh waktu fermentasi terhadap $\mathrm{pH}$

Gambar 4 menunjukkan bahwa pengaruh waktu fermentasi terhadap kandungan $\mathrm{pH}$, yang divariasikan dengan menggunakan volume effective microorganisme $\mathrm{EM}_{4}$, adalah seperti yang terlihat digambar pada waktu 10 hari dengan menggunakan volume $\mathrm{EM}_{4} 40 \mathrm{ml}, 50 \mathrm{ml}$, dan $60 \mathrm{ml}$, kandungan $\mathrm{pH}$ yang tertinggi diperoleh pada volume $\mathrm{EM}_{4} 40 \mathrm{ml}$ yaitu dengan kandungan pH 5,70, hal ini disebabkan karena dipengaruhi oleh beberapa faktor pertumbuhan mikroorganisme seperti suhu yang tidak stabil, nutrient, dan kondisi lingkungan (Briliantono, 2004). 
Waktu 13 hari kandungan $\mathrm{pH}$ yang diperoleh 5,58 pada volume $\mathrm{EM}_{4} 40$ $\mathrm{ml}, 5,57$ pada volume $\mathrm{EM}_{4} 50 \mathrm{ml}$, dan 5,56 pada volume $\mathrm{EM}_{4} 60 \mathrm{ml}$, hal tersebut menunjukkan bahwa kandungan $\mathrm{pH}$ yang didapat mulai menurun dengan lamanya hari fermentasi dan juga semakin besar volume $\mathrm{EM}_{4}$ yang diberikan, dan juga hal tersebut dipengaruhi karena pada waktu 13 hari tejadi pembelahan sel yang sempurna dibandingkan dengan waktu fermentasi lainnya, dan dapat menunjukkan bahwa kandungan $\mathrm{pH}$ yang terbaik diperoleh pada waktu 13 hari dengan volume $\mathrm{EM}_{4} 60 \mathrm{ml}$, dan sesuai dengan standar mutu pupuk organik cair (SNI : 19-7030-2011) (Briliantono, 2004).

Waktu 16 hari nilai $\mathrm{pH}$ yang diperoleh semakin menurun drastis, dan nilai pH yang sangat rendah ada pada hari ke 16 dengan volume $\mathrm{EM}_{4} 60 \mathrm{ml}$, dengan pH yang didapat 5,50, hal tersebut disebabkan karena mengalami fase logaritmik yaitu jasad renik membelah dengan cepat dan sudah mulai konstan, dan juga dipengaruhi oleh bakteri-bakteri yang berperan dalam proses fermentasi juga sudah mulai netral. Pada fase ini juga sangat dipengaruhi oleh medium tempat tumbuhnya bakteri dan juga kandungan nutrient dari bakteri sudah mulai menipis, kemudian kondisi lingkungan termasuk suhu dan kelembapan udara sangat mempengaruhi hal tersebut (Briliantono, 2004).

\section{Simpulan dan Saran}

Berdasarkan hasil dan pembahasan dapat diambil kesimpulan sebagai berikut:

1. Limbah padat buah-buahan dapat dijadikan sebagai bahan baku pembuatan pupuk organik cair dengan penambahan beberapa bahan lainnya.

2. Waktu fermentasi limbah buah-buahan yang terbaik yaitu pada waktu 13 hari dengan menggunakan bio aktivator effective microorganisme $\left(\mathrm{EM}_{4}\right)$ $60 \mathrm{ml}$.

3. Kandungan unsur hara makro $(\mathrm{N}, \mathrm{P}, \mathrm{K})$ pada pupuk organik cair yang terbaik adalah pada waktu fermentasi 13 hari dengan volume bio aktivator 
effective microorganisme sebanyak $60 \mathrm{ml}$ yaitu, untuk Nitrogen $(\mathrm{N})$ 13,4 $\%$, untuk Phosfor $\left(\mathrm{P}_{2} \mathrm{O}_{5}\right)$ 10,92\%, dan untuk Kalium $\left(\mathrm{K}_{2} \mathrm{O}\right) 6,39 \%$.

4. Kandungan $\mathrm{pH}$ yang terbaik diperoleh pada pupuk organik cair yaitu $\mathrm{pH}$ 5,56

5. Waktu fermentasi dan volume bio aktivator $\mathrm{EM}_{4}$ sangat berpengaruh terhadap kadar unsur hara makro $(\mathrm{N}, \mathrm{P}, \mathrm{K})$.

\section{Daftar Pustaka}

Amurwaraharja. 2006. Analisis Teknologi Pengolahan Sampah dengan Proses Hirarki Analitik dan Metode Valuasi Kontingensi Studi Kasus di Jakarta Timur. Makalah Falsafah Sains. Bogor: Institut Pertanian Bogor, Ilmu Pengolahan Sumber Daya Alam dan Lingkungan Program Pascasarjana.

Briliantono E. 2004. Produk Pangan Organik Kian Diminati Bisnis. Diakses tanggal $27 \quad$ Desember 2017 dari http://www.Bisnis.com/pls/portal30/url/page/home_page.

Damayanti sinaga. 2009. Pembuatan Pupuk Cair dari Sampah Organik dengan Menggunakan Boisca sebagai Starter. Skripsi. Medan : Universitas Sumatera Utara.

Djumarni, N., Kristian, B.S., Setiawan. 2005. Cara Tepat Membuat Kompos. Jakarta : Agromedia Pustaka.

Fitriani, Y. 2008. Pembuatan Pupuk Organik Cair dari Limbah Cair Industri Perikanan Menggunakan Asam Asetat dan EM4 (Effective Microorganisme 4). Skripsi. Bogor : Institut Pertanian Bogor.

Hadisuwito, S. 2007. Membuat Pupuk Kompos Cair. Jakarta : PT Agromedia Pustaka.

Hery. 2011. Kiat Pintar Memproduksi Kompos dengan Pengurai. Yogyakarta: Lily Publisher.

Indriani, Y.H. 2004. Membuat Kompos Secara Kilat. Jakarta : Penebur Swadya.

Litauditomo. 2007. Mengolah Sampah Rumah Tangga. http://www.lintauditomo.muliply.com. Akses 09 September 2017.

Maesono dan Paulus. 2001. Pupuk Akar Jenis dan Aplikasi. Jakarta : Penebar Swadaya.

Purwendro. S., dan Nurhidayat. 2006. Mengolah Sampah untuk Pupuk dan Pestisida Organik. Seri Agritekno. Jakarta : Penebar Swadaya. 
Riansyah Erwin dan Wesen Pupu. 2010. Pemanfaatan Lindi Sampah sebagai Pupuk Cair. Jurnal Ilmiah Teknik Lingkungan Vol. 4 No. 1. Universitas Pembangunan Nasional "Veteran" Jawa Timur.

Said, E. G. 1987. Teknologi Fermentasi. Jakarta: CV Rajawali.

Sarjono Siboro Erickson, Surya Edu dan Herlina Netti. 2013. Pembuatan Pupuk Cair dan Biogas dari Campuran Limbah Sayuran. Medan : Jurnal Teknik Kima Universitas Sumatera Utara.

Simamora, S., Salundik, Sriwahyuni dan Surajin. 2005. Membuat Biogas Pengganti Bahan Bakar Minyak dan Gas dari Kotoran Ternak. Bogor : Agromedia Pustaka.

Tejasarwana. 1995. Mikrobiologi Dasar. Jakarta: Erlangga.

Yuli A. Hidayati, Kottelat M, Kartikasari SN, Anthony JW. . 2011. Kualitas Pupuk Cair Hasil Pengolahan Fesses Sapi Potong Menggunakan Saccharomyces Cereviceae. Jurnal Ilmu Ternak Vol. 11, No. 2.

Yowono, D. 2006 Dengan Cara Aerob Maupun untuk Menghasilkan Kompos yang Berkualitas. Jakarta : Penebar Swadaya. 